\title{
TRAUMA AND IDENTITY: ON STRUCTURAL PARTICULARITIES OF ARMENIAN GENOCIDE AND JEWISH HOLOCAUST ${ }^{1,2}$
}

\author{
Harutyun Marutyan
}

Comparison of the Armenian Genocide and Jewish Holocaust memories allows us not only to discuss questions important for Armenian sociopolitical and scientific thought regarding the start of the 21 st century, but also for deriving useful lessons. The problems are examined from the point of view of memory studies and identity politics. The internationally recognized term "Holocaust" was used to characterize the Armenian massacres as far back as the end of the $19^{\text {th }}$ century - beginning of the $20^{\text {th }}$ century. The perception of a "unique" Holocaust and "primacy" of the Armenian Genocide in the 20th century are actually different characteristics of the same phenomenon: in the case of examination of the question from this point of view, the factor of "historiographical competitiveness" is gaining a secondary role, although it still exists in different manifestations of the collective memory. Giving priority to the ideological factor in the assessment of the organization and implementation of genocides allows Jews and Armenians alike to avoid the manifestations of ethnic opposition and to appear to the world in a more (from the point of view of Western values) preferable fashion. The Jewish institute of The Righteous Among the Nations cannot serve as a model for Armenians because of the absence of the factor of unselfishness (in a great variety of cases) in the rescue of Armenian lives. In the Jewish, as well as in the Armenian memory, there is a fight against the stereotype of "being slaughtered like sheep": in the Jewish case, the activities are mostly transferred to the field of "moral resistance", while in the Armenian case, the resistance of the Armenian people has not been emphasized as has the Jewish struggles, underground fights and rebellions. The process of the Armenian Genocide memory becoming a part of the American national memory in its certain manifestations repeats the approaches of the Jewish community of the United States. There are also some similarities in the case of choosing the sites for memorials, etc.

Comparative historiography of peoples with similar historical fates contributes not only to scientific thought but to our common humanity. In this regard, the comparison of the memories and identity politics of the Armenian Genocide and the Jewish Holocaust allows

1. To cite this article: Harutyun Marutyan, "Trauma and Identity: On Structural Particularities of Armenian Genocide and Jewish Holocaust," International Journal of Armenian Genocide Studies 1:1(2014): 53-69

2.In memory of my teacher Mikhail G. Rabinovich and his wife Elena Poghosian.

Main ideas of this article were developed thanks to the scholarship of Center for Advanced Holocaust Studies, United States Holocaust Memorial Museum (Washington, D.C.), where I was Diane and Howard Wohl Fellow from September, 2009 to March, 2010. The opinions, arguments, and assertions here are mine alone and in no way should reflect adversely upon the generosity of that institution. Some parts of the article were used during my presentations at CAHS fellows' seminar (January 20, 2010) and at the Caucasus Connections conference (Indiana University, Bloomington, April 5, 2014). The Armenian version of the article is published in Patmabanasirakan handes [Historical-Philological Journal] 2 (2011): 24-46. 
us not only to discuss questions that hold value for Armenian sociopolitical and scientific thought of the start of the $21^{\text {st }}$ century regarding the study of Armenian Genocide, but also to derive valuable lessons with far reaching consequences. Most importantly, these lessons contribute to the prevention of future genocide. A number of scholarly articles have been written on the subject of comparison of the Armenian Genocide and Jewish Holocaust, by Armenian, as well as Jewish and American researchers. ${ }^{3}$ My task is not to add new research to this list. It is rather to consider how the memories of the Genocide and of Holocaust are perceived, and how they work to stimulate people to act.

\section{Identity and Naming Dramatic Events of the Past}

As it is known, the word holocaust was originally derived from the Greek word holokauston, meaning "a completely (holos) burnt (kaustos) sacrificial offering" to a god. "Shoah" (calamity) is the Hebrew term for the Holocaust. It is used by many Jews, as well as a growing number of other people, due to theological discomfort with the literal meaning of the word "Holocaust"; these groups believe it is theologically offensive to imply that the Jews of Europe were a sacrifice to God. Nevertheless, today whenever the word "Holocaust" is used, despite the opinions of different scholars about its semantic boundaries, people understand that it refers to the killing by Nazis and their allies of six million Jews during the Second World War. Though this term denotes a phenomenon known to practically everybody, it has become thoroughly associated to a specific ethnic group: the Jewish people. Armenians too have their own term for their genocide (which has purely Armenian usage) - "Metz Yeghern" (the great calamity). The Armenian word "yeghern", connoting such meanings as "evil, peril, crime, disaster, accident, [and] loss," has long been used in Armenian medieval literature", while the term "mets" refers to the great scale of this calamity. After the events of 1915 and before the term "genocide" gained wide circulation in the mid-1960s, the term "Metz Yeghern" was used to describe the large-scale massacres carried out by the Turks and the Kurds in the Ottoman Empire. Today the terms "Metz Yeghern" and "Genocide" are still synonymous to the Armenian

3. See, for example: Franklin H. Littell, "Holocaust and Genocide: The Essential Dialectic," Holocaust and Genocide Studies 2: 1 (1987): 95-104; Vahakn N. Dadrian, "The Convergent Aspects of the Armenian and Jewish Cases of Genocide. A Reinterpretation of the Concept of Holocaust," Holocaust and Genocide Studies, 3: 2 (1988): 151-69; Robert F. Melson, "The Armenian Genocide as Precursor and Prototype of Twentieth-Century Genocide," in Is the Holocaust Unique?: Perspectives on Comparative Genocide, edited with an Introduction by Alan S. Rosenbaum, with a foreword by Israel W. Charny (Colorado and Oxford: Westview Press, 1996), 88-93, 97; Vahakn N. Dadrian, "The Comparative Aspects of the Armenian and Jewish Cases of Genocide: A Sociohistorical Perspective," in Is the Holocaust Unique?, 101-35; Idem, "The Historical and Legal Interconnections Between the Armenian Genocide and the Jewish Holocaust: From Impunity to Retributive Justice," The Yale Journal of International Law 23: 2 (Summer 1998): 503-59; Tigran Matosyan, Hayots tseghaspanutyun yev hreakan Holoqost: hamematman pordz [Armenian Genocide and Jewish Holocaust: Attempt of Comparison] (Yerevan: Hayots Tseghaspanutyan Tangaran-Institut, 2005) (in Armenian); Donald Bloxham, "Organized Mass Murder: Structure, Participation, and Motivation in Comparative Perspective," Holocaust and Genocide Studies 22: 2 (2008): 203-45. See for details: Tigran Matosyan, op. cit., 4-12.

4. Gabriel Avetikian, Khachatur Syurmelian, and Mkrtich Avgerian. New Wordbook of Old Armenian, volume 1 (Yerevan: Yerevan University Press, 1836/1979), 654 (in Armenian). 
people, and have almost identical usage. ${ }^{5}$ However, when President Obama used "Medz Yeghern" in his statements of April 24, 2009-2014 addressed to Armenians, the term was legally far from being an equivalent of "genocide," and did nothing to assist the cause of international recognition of the Armenian Genocide. By the way, the same formulation was once used by Pope John Paul II. ${ }^{7}$

The translation of "holocaust" in Armenian, "voghjakizum," manifests certain ambiguity: the first part of the term, "voghj," has the meanings - "all" and "alive," while "kizum" means "burning." Thus the term can also be understood as "burning alive." Maybe this is what Vahakn Dadrian, an outstanding specialist of the history of the Armenian Genocide, had in mind when comparing the Jewish Holocaust with the Armenian Genocide:

In one particular respect ...the Armenian experience of World War I comes closer to the concept of holocaust than the Jewish one, in the strictest sense of the word. Tens of thousands of Armenians were burnt alive in several regions of the interior of Turkey. Whereas in the Jewish case the gas chambers almost always preceded the ovens, in the Armenian case the stables, haylofts, barns and pits were inexorably substituted for both contraptions. ${ }^{8}$

While historians are well aware of the facts about Armenians having been burnt alive by the Turks, ordinary citizens have this memory mainly as a result of literary works. Of these, the most vivid is a poem by Siamanto (Atom Yarjanian), a Western Armenian writer and a victim of the Genocide, called, "The Dance," which, long ago, was included in Armenian school curricula. The poem describes an episode from the 1909 massacres in Cilicia, when Turks stripped Armenian women and made them dance, and then poured "a barrel of oil" over the naked bodies to burn them alive. It is in this poem that the expression "O, human justice, let me spit at your forehead" was first used. Later, due to its expressiveness and pathos, it became a much used adage in the posters of the Karabagh Movement (1988-1990). ${ }^{9}$ Another work, Zareh Vorberian's “The Blazing Dance," published in 1965, in Beirut, describes a similar episode after the defence of Urfa (formerly Edesia). It is characteristic that, conditioned by the above-mentioned works yet dormant, this memory came to the foreground only after the Sumgait events (February 27-29, 1988), where the Azerbaijanis identified with Turks applied the same methods to half dead Armenians. ${ }^{10}$

5. In the Google search system the term "Holocaust" appears 5.07 million times, "Shoah" - 0.73 million times, "Armenian Genocide" - 0.36 million times and "Medz Yeghern" - 0.03 million times (retrieved September 12, 2014).

6. See, for example: Rouben Adalian, "President Obama's Statement on the Armenian Genocide," The ISG Newsletter 42 (2009): 13.

7. http://www.genocide-museum.am/eng/Prayer_of_John_Paul_I_Memorial_of_Tzitzernagaberd.php

8. Vahakn N. Dadrian, "The Convergent Aspects of the Armenian and Jewish Cases of Genocide. A Reinterpretation of the Concept of Holocaust," Holocaust and Genocide Studies,vol.3, no.2 (1998): 165.

9. See for details, Harutyun Marutyan, Iconography of Armenian Identity. Vol. 1: The Memory of Genocide and the Karabagh Movement (Anthropology of Memory 2) (Yerevan: Gitutyun Press, 2009), 145-149.

10. The same type of crime was pictured also in Atom Egoyan's film "Ararat” (2002). 
I think it is relevant to note that as far back as in September 10, 1895, i.e. nearly 40 years before the Jewish Holocaust began, The New York Times headlined a story with the title, "Another Armenian Holocaust,"11 which described the Armenian massacres. During the last days of December of 1895, Armenians who had sought refuge in the Armenian Church of Urfa were brutally killed by Turks. A missionary, Ms. Corinne Shattuck, used the expression "a great holocaust" in her letter (published in The New York Times), underlining the religious aspect of the tragedy - Christian Armenians massacred by Muslim Turks and Kurds. ${ }^{12}$ In 1898, a socialist French-Jewish journalist, Bernard Lazare, called the slaughter of Armenians between 1894 and 1896 holocaust, and even Winston Churchill described the "massacre of countless thousands of defenseless Armenians" during the World War I as an "administrative holocaust." 13 Duckett Z. Ferriman's The Young Turks and the Truth about the Holocaust at Adana in Asia Minor, during April, 1909 was published in London in 1913, describing the massacre of the Armenians in Adana in $1909,{ }^{14}$ and was reprinted by the Armenian Genocide Museum-Institute in 2009.

\section{The Unique or Comparable}

Holocaust historians often separate the holocaust of Jews from other genocides of the $20^{\text {th }}$ century, defining it as an "unique" phenomenon not comparable with any other genocide. This is how it is both presented in professional literature and widely advocated. It is typical that such a formulation as "Holocaust and Genocide Studies" came to being and has become a separate academic trend. The main argument in its favor includes not only the wellorganized nature of the mass extermination of the Jews and its scale, but also the fact that the Jews were not offered or forced to change their religion in order to save themselves, whereas with Armenians it has been repeatedly stated that tens, or rather hundreds, of thousands of Armenians had been forced to accept Islam and thus to be saved.

Armenian historians more often put the emphasis on the facts that the Armenian Genocide was the first of the $20^{\text {th }}$ century as many of its methods were used in the Holocaust; while the mass killings were committed on the territory of origin of the victims and had led to its expropriation (which is also a unique fact with respect to genocides), etc. These two

11. http://query.nytimes.com/mem/archive-free/pdf?res=9D05E5DD113DE433A25753C1A96F9C94649ED$\underline{7 C F}$

12. "Three Days of Butchery; A Woman Describes the Massacre of Armenians in Ourfa. Not Less than 3.500 were killed. Terrible Slaughter in a Church." New York Times, February 17, 1896; Rouben Adalian, "Hamidian (Armenian) Massacres," http://www.armenian-genocide.org/hamidian.html; Richard Hovannisian, "The Armenian Question in the Ottoman Empire 1876 to 1914," in The Armenian People from Ancient to Modern Times, ed. Richard Hovannisian, Volume II (New York: St. Martin's Press, 1997), 223.

13. Winston Churchill, The World Crisis, vol. 5, Aftermath 1918-1928 (New York: C. Scribner's sons, 1929), 157; Tessa Hofmann, "The Affirmation of the Genocide of the Armenians. A Human Rights Defender's Point of View," http://www.proarmenia.am/eng-2003/en-Tessa Hofmann.htm; David B. MacDonald, Identity Politics in the Age of Genocide: The Holocaust and Historical Representation (London, New York: Routledge, 2008), 128.

14. Duckett Z. Ferriman, The Young Turks and the Truth about the Holocaust at Adana in Asia Minor, during April, 1909 (London, 1913); http://www.genocide-museum.am/eng/11.12.2009.php 
genocides do have in fact a number of comparable features. Still, each of them has also its own particular characteristics. Figuratively speaking, they can be described as the two faces of the same coin. From such a perspective it would seem that the separation intention fades considerably. In other words, adopting a comparable genocide studies' lens reveals that both Armenian and Jewish genocides have their own unique characteristics, for in both cases we come across certain phenomena that have occurred for the first time either in the Armenian, or the Jewish genocide. This is an issue, e.g., the differentiation of the Jewish Holocaust from other types of Genocides that can be addressed and can help to resolve or overcome certain difficulties encountered by historians with regards to the similarity and/or difference of the phenomena, even though the "uniqueness" perception and stereotypes will persist for quite a long time. ${ }^{15}$

\section{Who is to Blame?}

For several decades now in discussions of the Holocaust, Jewish and American scholars (at least in the USA and the European countries) have emphasized that the guilt is neither with the "Germans" (as a nation), nor with the peoples of Germany's allied countries in World War II, but with the SS, Nazism, fascism, racism and other equivalent ideologies. In other words, they do not give an ethnic qualification to the conflict that took place in the past, but view it as the result of a criminal ideology. Even if some researchers try to put a share of guilt on ethnic Germans or any other of the common people (a most vivid example is Daniel Goldhagen's publication of 1996 in New York: Hitler's Willing Executioners. Ordinary Germans and the Holocaust, ) notable negative responses ensue in both historiographical (including that of the great majority of Jewish authors) and related circles. In the above-said case, the negative response had been so strong that it gave rise to the notion known as "The Goldhagen's Effect."

For nearly a century, Armenian historians have emphasized the ethnicity of the perpetrators of the genocide. Of course, the ideology of the Young Turks has been voiced and written about, and yet the emphasis, in my opinion, has mostly been on the ethnicity of the genocide perpetrators. Such an emphasis may also be conditioned by the level of relations with the side of perpetrators and their legal successors. In the case of the Armenians, the responsibility for the present state of affairs lies first and foremost with the Turkish policy of denial.16 In turn, this policy has led to the centuries-old persistence of the stereotype of "eternal friends and enemies" (H.J.T. Palmerston). This policy has also been responsible for the stereotype's duration and its active role in contemporary political and civil life. As a consequence, for as long as the Armenian Genocide remains unrecognized by the legal successors of the state that committed it, and for as long as the phenomenon of the "genocide" is not transferred from its current ethnic dimension to that of an ideology, Armenians will have "eternal enemies," which will automatically make room for the presence of an "eternal friends."

15. By recognizing the common features of genocides as well as their unique characteristics, the comparative approach contributes to preventing future genocide and to ending those that are still ongoing.

16. According to Gregory Stanton, "Denial is the final stage that lasts throughout and always follows a genocide." http://www.genocidewatch.org/genocide/tenstagesofgenocide.html 


\section{Righteous or Mercenary?}

During the years the Holocaust was perpetrated, a vast number of people saved several individual to several thousand Jews, often at the risk of their own lives and that of their relatives. Later, the Jewish people created a rather extensive list of foreigners who had rescued Jews, "The Righteous among the Nations," 17 thus, also indirectly fighting any possible manifestations of xenophobia among Jews. The fact is that during the Holocaust, not only the Germans but also their allies had been engaged in the annihilation of Jews, be they government officials or common citizens. This was due to the fact that antisemitism had not been a singularly German attitude. Jewish researchers who created "The Righteous Among the Nations" list, would, as they say, think twice before they did something. One of the most significant criteria for being included in the list had been the selflessness of the often self-sacrificing assistance. This gave an opportunity to Jews and their future generations to avoid becoming racist. In revealing that, some of the peoples of Europe would do anything to help Jews - often complete strangers - in the time of need, the realization that true humanism was extant among many non-Jews and that manifestations of anti-Semitism had been mostly caused by Nazi propaganda.

Such an attempt was not made in the case of Armenians. There have been considerably fewer instances of manifestation of selflessness in rescuing the lives of Armenians. Those "saved" were, as a rule, either suggested to have adopted Islam, or, in case of women and girls, to marry their "saviors", or were exploited as additional labor hands and used otherwise, mostly with motives of self-interest. Still, as they say, "a negative answer is nevertheless an answer." In any case, such a study would be of great help for a more accurate evaluation of the ethnic factor in the occurrences of the beginning of the $20^{\text {th }}$ century, as well as for the interpretation of genocide memory and the elucidation of a number of issues related to the construction of Armenian-Turkish relations.

\section{Victim or Fighter?}

The presence of the genocide memory has significance in the Armenian system of perceptions and culture, as well as in its interaction with the rest of the world. Just as other peoples of the world do not reject the "burden" of their past, which is part of their identity, Armenians cannot abandon the legacy of the memory of their difficult past. Moreover, it is typical to have numerous international parallels, which is far from being detrimental.

This emphasis is conditioned by the recent development of a growing belief among some layers of the Armenian society, mostly the youth, that enough has already been said concerning the genocide: it distorts the psychology of our children and youth, and contributes to increasing xenophobia, etc.

An important aspect of this issue is the fact that when speaking of the Genocide, emphasis on the mass extermination of Armenians in Armenian-inhabited areas of the Ottoman Empire, the inhumane sufferings of deported Armenians in the deserts of DeirZor, and the fact of the helplessness of people doomed to be gradually annihilated can hardly be avoided. Due to this emphasis, certain members of society believe that the Armenians

17. See for details, for example: http://www1.yadvashem.org/yv/en/righteous/about.asp, http://www1. yadvashem.org/yv/en/righteous/statistics.asp 
were slaughtered like sheep, while showing almost no resistance. Such a representation and the equivalent perception of the fact of Genocide and the build-up of the national identity on that basis was largely contributed to by the works of talented Armenian writers in the Soviet period (especially the period from the end of the 1950s and the 1960s) on the theme of the Genocide. Such writers include Paruyr Sevak, Hovhannes Shiraz, Silva Kaputikian, Gevorg Emin and Hrachya Kochar who have produced some of the best-loved classics of several generations. However, an important circumstance has been overlooked. In fact, the Soviet leadership, particularly from the second half of the 1950s, did not so much forbid discussion of the Genocide, as it did foster the retention of memories in which Armenians were exclusively presented as innocent victims who had lost the greater part of their historical homeland and therefore needed sympathy.

Likewise, in Armenian historiography, emphasis was placed on descriptions of the Genocide and on collecting related documents, on verifying the number of victims, criticizing the Turkish policy of denial, and, later, on highlighting heroically fought battles. It is true that Armenian historians have highlighted and are continuing to write about the well-known self-defense battles at Van, Shatakh, Shapin-Garahisar, Musa Ler, Hajen, Urfa and other places. Still a very important circumstance is being left out in this matter: nothing is said from the perspective of historiographic evaluation about the fact that in both large and small villages, Armenians put up resistance, whether for a day or two, or a week or two, and that in one Armenian settlements or another, families fought deadly battles against the enemy, even if these battles only lasted for a couple of hours. Once again, note that such episodes have been described as separate facts/microhistories, yet, there have been no attempts of generalization or of presenting them as a qualitative phenomenon. In many instances (which is measurable) Armenians did not docilely wait to be slaughtered. It is difficult to explain the reasons why the issue is not analyzed from this standpoint. Among other things, not least important is the fact that for decades only historians, for whom "facts" are often identified with "documents," have engaged in the study of the genocide issues, whereas most of the materials referred to in this study do not belong to that category.

The situation has not much changed in recent years. Thus, when April arrives, the Armenian mass media abounds with the theme of sadness: the innumerable innocent victims are remembered as well as the lost historical homeland, etc. The situation changes radically with the arrival of May, a month that is rightfully considered "a month of victories," probably because of the Battle of Avarayr (451), the Battle of Sardarapat (1918), the victory in the Great Patriotic War (1945) and the liberation of Shushi in the more recent past (1992). The list of the official holidays does not include the heroic struggle of Van and its victory (1915). The struggle had begun in April (April 7) and was over in May (May 3), having lasted only 27 days, yet resulted in the saving of at least 200 thousand lives of the people of Van-Vaspurakan. If the Armenian Parliament adopted April 7 (or April 19 according to the new style) as Self-Defense Day (even if leaving it a working day), the grave symbol of April as a month of mourning could be gradually changed, or at least be an aid in renaming "a month of struggle and remembrance."

In the case of Jews, instances of armed resistance in the years of Holocaust had been relatively fewer, or, to be more accurate, different by nature (participation in the underground and thus in the Resistance; in the guerrilla movement; resistance in concentration camps, 
etc), yet the Holocaust historians consistently pay much attention to this theme and, in particular, to the Warsaw Ghetto Uprising (April-May, 1943). Note that the fact that the Holocaust Commemoration Day in Israel is officially called "Holocaust and Heroism Remembrance Day" or "Holocaust Martyrs' and Heroes' Remembrance Day," the museum - "Yad Vashem: The Holocaust Martyrs' and Heroes' Remembrance Authority" has been conditioned, among other factors, by this as well. The researchers engaged in the study of the history of Holocaust see the solution of the problem in extending the boundaries of the issue and naming it the "Jewish response" or giving other similar definitions. In this case numerous instances of moral resistance come to the foreground, which at least shakes the decades-old stereotype that the Jews had been "slaughtered like sheep" - a definition that, as noted above, emerging in some circles of present-day Armenian society, leads to manifestations of an inferiority complex, to instances of the perception of the memory of genocide as a burden, and to a recognition of the need for action towards discarding it.

The stereotype "slaughtered like sheep" long persisted among the Jews as well. The fact that the attitude towards the survivors of the Holocaust used to be quite different in the first two decades after the calamity is largely conditioned by this fact. It is a fact that the formation of the state of Israel was accompanied by large and small scale wars, which means that the Jews, unlike in Holocaust years, fought with weapons against the enemy. They were warriors and fighters, and it was considered that the image of a survivor of Nazi horrors would do nothing to inspire them. Only with the пассаге of time this attitude started to change gradually and the recognition of the stories of the survivors and their experiences became a social requirement.

\section{The Forty Days of Musa-Dagh and Jewish Resistance}

It is characteristic that in the Jewish ghettos (including those in Warsaw) and in the underground that showed resistance to Nazism or seeked to do so, Franz Werfel's novel, "The Forty Days of Musa Dagh," was widely read. This novel, according to the eyewitnesses, inspired those who struggled against unequal forces, making them confident of their own strength. As Yair Auron, one who has studied the issue meticulously, notes, ${ }^{18}$ Musa Dagh has often been compared to the resistance in the Jewish ghettos during the World War II.19 The Jewish underground organizations which operated in the ghettos during the Nazi occupation of Europe, intensely debated the purpose of their struggle and the meaning of their lives and death in their harsh reality. ${ }^{20}$ Several records from their shocking and fascinating discussions, highlighting moral and existential Jewish dilemmas, were found. One of these is the minutes of a general meeting of Kibbutz "Tel Hai," a group of Jewish activist youth

18. See for details: Yair Auron, The Banality of Indifference: Zionism and the Armenian Genocide (New Brunswick (USA) and London (UK): Transaction Publishers, 2000), 293-311. See also: Hans Wagener, Understanding Franz Werfel (Columbia, South Carolina: South Carolina University Press, 1993), 115-124; Yair Auron, "The Impact of Jewish Youth in Palestine and Europe," in Remembrance and Denial: The Case of the Armenian Genocide, ed. Richard G. Hovannisian (Detroit: Wayne State University Press, 1999), 147-164.

19. Yair Auron, The Banality of Indifference, p. 293.

20. Ibid, p. 301. 
in Bialystock (northeast Poland), on February 27, 1943. During the discussion, one of the central figures of the organization, Herschel Rosenthal, suggested viewing the ghetto as "our Musa-Dagh," and so adding "a chapter of honor to the history of Jewish Bialystock and of our movement." ${ }^{21}$ In May 25, 1943 commander of the Bialystock underground Mordechai Tenebaum wrote: "Musa-dagh is all the rage with us. If you read it ["The Forty Days of Musa Dagh"], you will remember it for the rest of your life."22 According to Chayka Grossman, one of the leading figures in the leadership of Socialist-Zionist youth movement in Bialystock, copies of the book had been "passed from hand to hand" among the ghetto's defenders, who compared their situation to that of the Armenians. ${ }^{23}$ The same appreciation of this book appeared in the Sosnovitz (southern Poland), Kovno (Kaunas, Lithuania), and Warsaw ghettos youth. Another Jewish researcher recalled the impact of Musa Dagh on Yitzhak Zuckerman (Antek), who was one of the leaders of the Warsaw Ghetto Uprising. In his journal, the chronicler of the Warsaw Ghetto, Emmanuel Ringelblum, compared the situation in the ghetto with that of Musa Dagh. ${ }^{24}$

The book was also influential in the Western European underground. Members of the Dutch underground read the book in German. "It was a 'textbook' for us," one of them wrote, "it opened our eyes and spelled out for us what might happen, although we did not know what in fact would occur." 25

The examples cited above indicate the importance and significance that Jewish youth movements attributed to "The Forty Days of Musa Dagh," probably before the World War II and certainly during it. The book was an example, a reference, and, to some extent, a model to be admired and imitated.

In a publication on the life of the Jewish ghettos in the Nazi years, it is stated that ${ }^{26}$ during the Second World War the most widely read books among adults were "The Forty Days of Musa Dagh" and "War and Peace" by Leo Tolstoy. As Yair Auron indicates, it seems that the magnetism of Musa Dagh which became a symbol for the Jewish underground's resistance fighters resulted from the powerful text. During the period of the ghetto, the reality of the ultimate victim became clearer and clearer, at least to the members of the underground. There was, nonetheless, a notion of dignity and self-respect; an admiration for the victim who struggles, rebels, strives for freedom, and maintains his dignity even after his fate is doomed. Even the dilemma so widely posed in the context of the Holocaust - "going like sheep to slaughter" - appears numerous times in "The Forty Days of Musa Dagh," where the characters state that they have no wish to die in this manner. In this sense the reading of the book fortified the spirit of its readers, future underground fighters, as Mordechai Tenebaum and other underground leaders have suggested.

21. Ibid, p. 302.

22. Ibid.

23. Ibid.

24. Ibid, p. 306:

25. Ibid.

26. Ibid. The author states that (p. 311) he found the information in: David Shavit, Hunger for the Printed World: Books and Libraries in the Jewish Ghettoes of Nazi-Occupied Europe (Jefferson, North Carolina (USA), and London: McFarland \& Co., Publishers, 1997). 
Let me emphasize once again: for the members of the Jewish underground the story of the defense of Musa Dagh was a parable, a model and a source of inspiration. They equated their own fate to that of Armenians. In both cases, the persecutor's purpose was the uprooting, the exile, and the physical annihilation of entire communities, and in both cases, resistance embodied the idea of an honorable death as a nation, or a chance to be saved as individuals.

\section{Global Response and State Formation}

The evaluation of the forms of the world's response to the Jewish and Armenian genocides is closely linked with the Armenian identity and with certain elements of the system of Armenian perceptions. Now then, has the world's attitude always been indifferent to Armenians? Armenians have commonly maintained the perception that the Great Powers have usually sacrificed the interests of the Armenian people at their convenience, have denied help in the time of need, etc, in order to achieve their own goals and serve their own interests. I believe that this is a rather typical example, not in relation to Armenians only, but to many other nations of the world, of an approach taken when a society due to objective or subjective, or both objective and subjective reasons is unable to solve a certain problem unassisted, seeks to put the blame for its failures on someone from outside. Thus, even before the end of World War I, Eastern Armenians managed to proclaim the creation of the Republic of Armenia. Only a week later, the Batumi Treaty was signed with the state responsible for the Armenian Genocide, which significantly narrowed down the yet not clearly outlined boundaries of the Armenian state. Thanks to the victory of the Allied States, by the end of the war, the boundaries of the new founded Armenian state significantly expanded by the inclusion of the Kars region and other territories without any military action. On August 10, 1920 the Entente Powers and the Ottoman Empire signed the Treaty of Sevres, which claimed that the territory of Armenia was to be trebled. Yet Armenia was unable to repulse the recurrent attack of the Turks not long after the signing of the Treaty; the internal unrest played its role too. The fact remains that thanks to the assistance of the Great Powers, Armenia received the opportunity to become a de jure, powerful Middle Eastern state, whereas it failed to become de facto.

The course of events was different in the case of the Jewish people. Along with the spread of Zionist ideology, "Aliyah," the repatriation of Jews towards Palestinian territories began under the mandate of the Ottoman Empire and later of Great Britain yet populated predominantly by Arabs. In the years preceding the formation of the state, the population of the Jewish community of the area had reached 650 thousand people. The world at large did not particularly assist this repatriation: there were quotas fixed by the authorities of the British mandate which were regularly breached not as much with the connivance of the British, as by the mass nature of illegal immigration. The immigration was organized mainly by the effort of the Jews. Afterwards, the world, in response to the loss of the Jews and their persistence, allowed, by the UN decree, the creation of a Jewish state. Right after the proclamation of the state of Israel, in May, 1948, wars began with the neighboring Arab states. The newly created state withstood and even more - expanded its territory. In short, in the $20^{\text {th }}$ century, the Jews succeeded in singlehandedly establishing a more or less de facto (a mass presence in the Palestine) status, which was followed with some assistance by 
the Great Powers to establish a de jure status, creating a small, yet nonetheless powerful, Middle Eastern state.

So, in both the cases of the Armenians and Jews, the "world" has been both indifferent and compassionate. Still, the outcomes remain to be different.

\section{Crimes against Humanity}

After the defeat of Nazi Germany, the Allies organized an international court-martial for the chief Nazi war criminals that lasted for about nine months. The highest-ranking military officers and statesmen of Nazi Germany were called to answer. The Nuremberg trial unmasked the essence of German fascism, its plans for the annihilation of whole countries and peoples, and the hazard of fascism to mankind.

It is known from history that Pan-Turkism, too, pursued the extermination of whole countries and peoples. Similar to fascism, millions of people, mostly Armenians, fell victim to this ideology. As previously promised by the Allied states, the Pan-Turkist Young Turk leaders were tried after World War I, although the trial never saw a conclusion because of the inconsistency of the Allies themselves. As it later became apparent, the Allies did not wish to risk their future relations with the Turks, and had no intention of punishing the "Turk criminal." ${ }^{27}$ Moreover, they took them under protection.

And what happened next? In the words of Simon Vratsian, the last Prime Minister of the First Republic of Armenia:

A quarter of a century later, after World War II, in conditions very much the same, an international court-martial was held in Nuremberg for Nazi criminals. The Nazi leaders were executed and the German people were made to pay an indemnity to Jews, to calm the indignant conscience of the 'civilized humanity.' Different was the attitude of that same 'civilized humanity' with regard to Armenians. One half of the Armenian population of Turkey had been massacred in a most vicious way, the other half had been scattered all over the world. The property of Armenians was stolen. Towns and villages were deserted. And when the time arrived for indemnity, the 'civilized humanity' remained unconcerned. The Armenians organized, with the "sacred blood of their sons"...their own Armenian Nuremberg for the Turk butchers. [the emphasis is mine-H.M. $]^{28}$

With the efforts of the Armenian political party, "Armenian Revolutionary Federation," the "Nemesis" action was planned, and many of the organizers of the Armenian Genocide were assassinated by Armenian avengers. In the case of Jews too, despite the Nuremberg trial, right after the war in 1945, a number of groupings of Jewish avengers came to assassinate about 1500 or more SS officers and officials of various levels directly engaged in the actions for the annihilation of Jews. ${ }^{29}$ So, it can be stated that the response of the Armenians and the Jews with respect to vengeance has been identical.

27. S[imon] V[ratsian], "The Armenian Nuremberg," in Arshavir Shirakian, Ktakn er nahataknerun [It was the Will of the Martyrs] (Yerevan: Adana, 1991), 75.

28. Ibid, pp. 76-77:

29. See for details: Morris Beckman, The Jewish Brigade: An Army with Two Masters 1944-1945 (Staplehurst, Kent: Spellmount, 1998). 


\section{The Americanization of Genocide}

In the monograph devoted to the creation of the United States Holocaust Memorial Museum (USHMM), its author Edward T. Linenthal, used the following idea in his first sentence: "the Holocaust became an event officially incorporated into American memory." 30 The idea appears elsewhere in the book, when both positive and negative aspects of the "Americanization of Holocaust" are considered. ${ }^{31}$ As Linenthal notes when assessing the appointment of a Commission on the Holocaust in 1978 by President Carter, "he signaled that the Holocaust had moved not only from the periphery to the center of American Jewish consciousness, but to the center of national consciousness as well. Too important a story to be bounded by ethnic memory, it was, by virtue of its awesome impact, its poisonous legacy, and its supposed valuable "lessons," worthy of inclusion in the official canon that shaped Americans' sense of themselves." 32 On another page he notes that "The Report [created by the President's Commission on Holocaust] insisted on the Jewish core of the Holocaust. The event, it insisted, "is essentially Jewish, yet its interpretation is universal." 33 On yet another page, he presents the deputy director of the above mentioned Commission Michael Berenbaum's opinion that "The story [of Holocaust] would, however, have to be told in a way that would be meaningful to an American audience; it would have to move beyond the boundaries of ethnic memory." ${ }^{34}$ As a progress indicator of the phenomenon of "Americanization of Holocaust," Linenthal presents well known Holocaust scholar Raul Hilberg's opinion on the reason for the growing interest of university students in the US in courses on the Holocaust: "After the disorientation of Vietnam, they [Americans] wanted to know the difference between good and evil. The Holocaust is the benchmark, the defining moment in the drama of good and evil." ${ }^{35}$ The course taken by the Commission for the foundation of the Holocaust Memorial, even though criticized "in some segments of the American Jewish community," ${ }^{36}$ was nevertheless the only right one.

During my interview with the coordinator of the Armenian Genocide Museum of America, Dr. Rouben Adalian, I understood that the same approach was adopted by that museum. ${ }^{37}$ This approach was influenced by close observation of the foundation of the USHMM, and talks with Linenthal, as well as the understanding of Linenthal's book. Yet, if, in case of Holocaust, evil was punished in the highest international courts, and if many the perpetrators admitted their crime and have repented, the situation is very much different in the case of the Armenians. To this day, the international community has not

30.Edward T. Linenthal, Preserving Memory: The Struggle to Create America's Holocaust Museum (New York: Columbia University Press, 2001), 1.

31. Ibid, pp. 44, 216 etc. This phenomenon has been widely considered in many other works on Holocaust memory.

32. Ibid, pp. 12-13.

33. Ibid, p. 36.

34. Ibid, pp. 44-45.

35. Ibid, p. 11.

36. Ibid, p. 13.

37. H. Marutyan's personal archive, recordings. 
legally condemned the Armenian Genocide; Turkey refuses to acknowledge its factuality, insisting that it is a mere fabrication. And, there is no word of compensation on the part of the legal successors of the Ottoman Empire. In other words, evil has not been punished, and from this aspect, Armenians have yet a long way to go. For this reason, the Armenian Genocide Museum in the United States will have to widely display the facts of genocides that occurred in the world during the $20^{\text {th }}$ century, show how a rich historical-cultural heritage created over centuries was largely obliterated, and make future generations aware of the assistance of the American people to Armenians during and after the Genocide, and thus to make an attempt to link the history of the Armenian Genocide to $20^{\text {th }}$ century United States history. ${ }^{38}$

In both cases one can see an effort to take purely ethnic tragedies that were ethnic by nature, beyond the boundaries of ethnicity, and to present them to the world as "evil of international level." At least in case with USHMM, which has been functioning for 20 years already and has been visited by more than 37 million people, we are faced with facts that show what happens when basic American values are trampled. In particular, this direct link is evident in two inscriptions at the entrance to the museum, one of which is a quotation from George Washington, which reads: "The government of the United States... gives to bigotry no sanction, to persecution no assistance." ${ }^{39}$ Another indication of such an attempt can be considered the recognition by the General Assembly of the United Nations in October, 2006, of January 27 (the day of liberation, in 1945, of Auschwitz-Birkenau, the biggest Nazi concentration camp) as the Annual International Day of Commemoration in Memory of the Victims of the Holocaust. So, in addition to the Holocaust Remembrance Day, Yom Hashoah, observed in Israel and in countries with Jewish communities on the $27^{\text {th }}$ day of the Jewish month of Nisan, now another day is officially added to be observed by the international community. Thus the memory of the Holocaust is now officially accepted as an important part of the international memory of struggle against evil. So, when Armenian scholars and publicists, or ordinary people, compare the Armenian Genocide with the Jewish Holocaust, it is not only and not so much a wish to state a historical fact as a wish to make the Armenian Genocide part of international memory. One manifestation of this intention is the use of Holocaust-related terminology in publications on the Armenian Genocide in English (concentration camp, Armenian Nuremberg etc). This is also how I am inclined to interpret the following excerpt from Linenthal's book: "Each group [Polish, Armenians, Romani] argued that they belonged within the boundaries of the Holocaust, and then their representatives made a case for their "space," their position - always defined, however, in relation to the Jewish center." 40

38. See for details, for example: Rouben Adalian, compiler and editor, Guide to the Armenian Genocide in the U.S. Archives 1915-1918 (Alexandria, VA and Cambridge, UK, 1994); Peter Balakian, The Burning Tigris: The Armenian Genocide and America's Response (New York: HarperCollins, 2003); Jay Winter, ed., America and the Armenian Genocide of 1915 (Cambridge, UK; New York: Cambridge University Press, 2003).

39. http://www.ushmm.org/research/library/faq/details.php?lang=en\&topic=06\#quote washington

40. Edward T. Linenthal, op. cit., p. 249. 
In the process of becoming part of American memory, Armenians are trying to follow the example of the Jews. In particular, in a number of U.S. States, April 24 has been declared as Commemoration day of the victims of the Armenian Genocide, and forty-three states have officially recognized the Armenian Genocide. ${ }^{41}$ Still, it is not yet officially included in the American calendar. The issue of creating an Armenian Genocide Museum in Washington pursues the same objective. Note that when choosing the site for the museum, the American Armenians were comparing its location to that of the USHMM, which is openly implied in, for example, the "Armenian Genocide Museum of America" video clip. ${ }^{42}$

The Holocaust scholars have in their declarations repeatedly defined the occurrences of the beginning of the $20^{\text {th }}$ century as genocide. ${ }^{43}$ By contrast, in some cases Jewish lobbyists have opposed the efforts of Armenians to present the fact of Genocide to the American public. ${ }^{44}$ Among such recent instances were the activities of Anti-Defamation League (ADL), which aimed its efforts at denying the mass murder of the Armenians to be constituted as genocide. ${ }^{45}$ Linenthal considers the issue of inclusion of the Armenian Genocide in USHMM in detail. He points out the purely political reasons underlying the results, among them theses of the notion of the "uniqueness of the Holocaust" and the pressure of the Turks. ${ }^{46}$ In consequence, the Armenians at present are mentioned in USHMM only in the quotation attributed to Adolf Hitler, and the Armenian Genocide is mentioned but a couple of times in expert texts broadcast through monitors at Wexner Center. From September 27 till November 12, 2000, in the least visited part of the museum, in an inconspicuous corner in front of the Meyerhoff Theatre, a rather large screen titled "The Armenian Genocide" displayed pictures, maps, and texts on the issue. Note that rather primitive texts accompanied this temporary display: ${ }^{47}$ apart from the title, the word "genocide" occurs not once, and there are no parallels made with the Holocaust. On August 25, 2009, the series "Voice of America Press Releases and Documents," presented extracts from an interview with Bridget ConleyZilkic, project director of the USHMM's Committee on Conscience, in which a paragraph marked "Armenians in World War I" bore a line that reads: "Armenia is a controversial case

41. See, for example: "Genocide Awareness Act" Clears California State Senate. http://www.asbarez. com/2009/06/04/genocide-awareness-act-clears-california-state-senate/; Rouben Adalian, "President Obama's Statement on the Armenian Genocide," p. 13.

42. See the introductory video about the Armenian Genocide Museum of America, http://www. armeniangenocidemuseum.org/

43. See, for example: "Statement by 126 Holocaust Scholars, Holders of Academic Chairs, and Directors of Holocaust Research and Studies Centers. March 7, 2000," New York Times, June 9, 2000, http:// www.genocide-museum.am/eng/126.php

44. See, for example: Peter Novick, The Holocaust in American Life (Boston and New York: Houghton Mifflin, 1999), 192-193.

45. See for details: David Boyagian, "Confronting the Denialist Jewish Lobby: Mission Accomplished?" The Armenian Weekly, April 1, 2009.

46. See for details: Edward T. Linenthal, op. cit., pp. 228-239, Peter Novick, op. cit., pp. 192-193.

47. The document titled "Script Final. pdf" and the photograph were kindly given us by Edward Phillips, editor of "Genocide Prevention e-Newsletter" at USHMM, at the request of Steven Feldman. 
today...," "There is a lot at stake in being able to say that genocide happened."48 Such an attitude has its grounds: a museum is an official establishment and is obliged to demonstrate the operating doctrines of U.S. policy in its official information. Despite this official US policy, there is not one researcher in all the research departments of the museum who would question the fact of the Armenian Genocide. Articles on the topic are regularly published in the academic periodical of the museum, "Holocaust and Genocide studies."

\section{The Architecture of Genocide Memory}

Naturally, the "physical container" of the Holocaust memory, considered as an important part of American memory, couldn't have been situated in an ordinary location. On page two of Linenthal's book is written, that: "The dedication of a museum located adjacent to the ceremonial center of the nation, the Washington Mall, emphasized the Holocaust's place in the official memory of the nation." 49 Further on in the book, the author dwells in detail on the issues of place and site selection for the construction of the museum. Some characteristic quotes are: thus, the members of the President's Commission were of the opinion that "since this was to be a "national' memorial, Washington, D.C., was the proper location." Or "A museum built in New York, even if national in intent, would clearly be perceived as a Jewish museum built in the heart of the Jewish community in America. Memory of the Holocaust would remain the province of American Jews. A national museum in Washington, on the other hand, made a more expansive - and controversial - claim on memory." Or "What was more attractive, of course, was the site's location. Not only would there be a national museum to the Holocaust in the nation's capital, but, by virtue of its location just off the Mall, the museum would gain the prestige of a central national memorial." Or "For survivors, a museum within the monumental core was especially important. It was the logical extension of their desire and need to make Holocaust memory permanent" and "A museum at the heart of American commemorative space was viewed as an eternal insurance policy." ${ }^{50}$ As has been stated above, the AGMA will be located, if not on the Washington Mall perceived as the "ceremonial center of the nation," still on a site no less significant - only a couple of blocks, a few minutes' walk from the White House.

How, then, was the problem solved not abroad, in the Diaspora, but in the countries that stand for the sovereignty of the two peoples, the Jews and the Armenians, who have suffered genocide - in Israel and in the Republic of Armenia? Note that the territory of RA has not been part of the territory shown in maps in circulation for several decades, of the places where genocide was perpetrated. Similarly, nor was the Holocaust perpetrated in Israel. $^{51}$

48. When Can It Be Considered Genocide and Why It Matters. 1049 words. 25 August 2009. Voice of America Press Releases and Documents. CY Copyright (c) 2009 Federal Information \& News Dispatch, Inc. VOA English Service. Document VOA0000020090825e58p00037.

49. Edward T. Linenthal, op. cit., p. 2.

50. Ibid, pp. 57, 58, 59, 61, 63-72, 256.

51. Issues relating to the domain of studies of the Armenian Genocide memory that face the sociopolitical and academic thought of the beginning of the $21^{\text {st }}$ century are not limited to the above. Other domains 
Drawing parallels between the Genocide Memorial in Armenia and Yad Vashem in Israel is a matter of elaborate study. Here are some parallels: in Armenia, the wooded hill of Tsitsernakaberd was selected as a location for the construction of the Memorial Complex for the Victims of the Genocide. It was rather far, about an hour walk from the center of the capital. It is perceived as a cemetery, and the annual marches to the Memorial combine collective memory and burial rituals to become a particular manifestation of national identity. ${ }^{52}$ Mount Herzl, on the western slope of which Yad Vashem is located, is considered a national cemetery, where Jewish and Israeli national and public figures, as well as the fallen soldiers of the Israel Defense Forces are buried. Though Tzitzernakaberd is currently not a cemetery, it was during the Bronze Age (burial sites were found here in 1920s), and the part of the Complex showcasing the eternal fire has been designed as a crypt. It was due to this perception of the place as cemetery, too, that in 1991 some of the victims of the armed conflicts on the Armenian-Azerbaijani border were buried in the immediate vicinity of the Genocide Monument. The authorities, however, brought this practice to a halt. There is usually a chapel in or beside any Armenian cemetery. There is no chapel in the area of the Genocide Memorial complex. This "omission" seems to have been noted by the Church. On April 24, 2005 the Holy See of Echmiadzin placed a stone slab near the Monument, with an inscription stating that a chapel would be built there in the memory of the martyrs. ${ }^{53}$ There is a synagogue on the territory of Yad Vashem too. Though there is no structure intended for religious rites in USHMM, architecturally spiritual feelings impression is created by the Hall of Remembrance. In the Tzitzernakaberd museum, the religious element is manifested by its cross-like windows.

In the Armenian language, one of the synonyms for "cemetery" is the term "restingplace." ${ }^{54}$ It is considered important not to disturb the dead by locating places of worldly entertainment nearby. When in the mid-1980s the construction of a Sports and Concert Complex on the slope of Tsitsernakaberd hill was proposed, there was huge public opposition to the plan and its actual construction, which was considered sacrilegious. Critical remarks about a restaurant being located on the approaches of the Armenian Genocide Memorial can still be heard. There are several eateries functioning on the territory of the Memorial complex

for comparison between the Armenian and Jewish genocides are: the boundaries of "Genocide victim" concept in Armenian and Jewish cases; ways of "individualization" of the Holocaust; questions as to the survivors' telling what they have experienced; forms of pilgrimage to the "places of remembrance"; the specificies of memory preservation in homeland and diaspora; the forms of memory preserving (archives, museums, educational institutions); and the emphasises, the similarities and differences in the culture of memorialization; the ways of memory awakening and transforming it to a factor; the potential of Genocide/Holocaust memory; interrelation between memory and indemnification, etc.

52. See for details: Harutyun Marutyan, Iconography of Armenian Identity, 40-46.

53. It is of interest that the architect of the Armenian Genocide Memorial Mr. Sashur Kalashyan wrote an "open letter" (May 10, 2005) where he was categorically against the idea. Probably his architect's professional instinct told him that in that case the Memorial would completely acquire cemetery functions. His criticism was taken into consideration, but only partially: a chapel will be built on the territory of the complex, but farther from the Memorial itself than was originally planned.

54. See: St. Malkhasyants, Dictionary of Armenian Language, vol. III (Yerevan: State Press of Armenian SSR, 1944), 45. 
that have opened in the years after the declaration of independence. ${ }^{55}$ There is an opinion, that Tzitzernakaberd was deliberately chosen for the Sports and Concert Complex, in order to de-sanctify the territory. ${ }^{56}$

Each year on April 24 about one million people visit the Genocide Memorial Complex to pay tribute to the martyrs. In the years of the Karabagh Movement in 1988-1990, this pilgrimage often grew into political demonstrations with countless posters, banners and wreaths bearing political messages. An analysis of the posters seen at the Memorial clearly shows how the image of a victim pleading for justice was gradually replaced by that of a warrior who had realized that national objectives could be achieved through struggle only. ${ }^{57}$ Today, the Genocide Memorial Complex is Armenia's single venue in which all various political, economic, and non-governmental organizations have the opportunity to "mark their presence" once a year.

55. See for details: R. Arshakyan, "The "Bear-pit" Spreads its wings," Aravot, September 2, 2004N. Babayan, "Mourning and Carousing Side by side," Aravot, October 26, 2007; J. Hakobyan, "Cultural Conflict: Construction on the Territory of the Genocide Memorial Gives Rise to People's Discontent," http://www.armenianow.com/hy/features/7805/cultural clash_development_of geno, October 2, 2007;

56. The opinions were voiced in the discussions at the international conference, "From Memory to Remembrance," on the $40^{\text {th }}$ anniversary of the Tzitzernakaberd Genocide Memorial Complex (Yerevan, November 27-28, 2007) where I was present too.

57. See for details: Harutyun Marutyan, op. cit., p. 277. 